\title{
THE EFFECTIVENESS OF FLASHCARDS ON THE MOTIVATION TO INCREASE ENGLISH VOCABULARY AMONG THE FOURTH ELEMENTARY SCHOOL
}

\author{
${ }^{1}$ Helda Lisa \\ ${ }^{1}$ SMK Negeri 6 Bengkulu \\ Corresponding email: heldarisa4@gmail.com
}

\begin{abstract}
:
The primary objective of this study is to find out whether the illustrated flashcards have positive effect on the motivation to increase English vocabulary among elementary school fourth grade students. The problem of this study is why students of elementary school fourth-grade still find difficulties in understanding and comprehending the English material and especially that for vocabulary. The result of the analysis shows that there is a significance difference between the motivation to learn English vocabulary among the elementary school fourth-grade students before the implementation of flashcards and that after the implementation $(76,6 \%)$, and there is a significant difference between English vocabulary mastery of elementary school fourth-grade students taught by using flashcards and that of those taught without using flashcards $(\mathrm{t}=7,74)$.
\end{abstract}

Keywords: Educational Media, Illustrated Media, Flashcards, Motivation, Vocabulary

\section{INTRODUCTION}

Based on the status of English in Indonesia, learning English can be said as learning a foreign language. This condition leads to some general idea about learning English in Indonesia. One obvious thing is that generally people start learning it when they enter junior high school at the age of around thirteen. Only on the basis of the 1994 elementary school curriculum people in general can start learning it in elementary school. However, English in this level is considered only as a local content subject, which means that not all schools implement it in their instruction. And, because learning English in Indonesia happens in schools, automatically what the students learn always refers to the curriculum.

The English instruction in Elementary school is intended to endorse the mastery and development of the four basic abilities and skills, that is, reading, listening, pronouncing and writing as reflected in abilities and skills 
concerning language use so that students are able to expres simple expressions with emphasis on vocabulary mastery.

In order that vocabulary instruction will attain better outcomes, the teacher should choose an appropriate teaching method which is suitable with the subject matter in the teaching learning process. He needs to use various instructional media that will be able to help students increase their English vocabulary. As a new subject, English is still likely to be regarded strange by the elementary school students when they get the lesson for the first time, so that they will find difficulties in understanding and comprehending the material, especially for the vocabulary. It is one of the reasons that causes students' motivation to be low in learning English.

The assumption that elementary school students' characteristics in teching learning activities is that they mostly use their sense of sight. It intensifies the reason for the teacher to use visual media. There are many kinds of visual media ranging fro the simplest one to the most complicated ones whether they are illustrated or not. The illustrated flashcards is one of the simple illustrated visual media to facilitate students' method of learning. It is easy to be understood and comprehended by them and easy to be made as well as cheap.

Educational media as a teaching aid can be used to enhance the effectiveness of the teaching learning process to obtain the instructional objective. These media consist of various kinds of each kind has its own characteristics.. Therefore, the use of media is very much recommended in learning activities and the teacher should be deeply careful to choose the appropriate media.

Hamalik (1985) states that illustrated media are pictures which are not projected. Among the educational media, the illustrated media are the most common media to be used. Visual media in relation with the human beings' ability to memorize have the highest percentage. Based on the research done by Education Projection ( in Rinanto, 1982) in the United States about the human being's ability to memorize through the five sense, the data on the ability are as follows:

1) Sense of taste : $2 \%$

2) Sense of smell : $3 \%$

3) Sense of touch : $5 \%$

4) Sense of hearing : $30 \%$ and

5) Sense of sight : $60 \%$

From the data stated above, it is clear that visual media, which include illustrated media, are more adventagious than any other media. They involve the sight. The students are assumed to be more effective to study English when they involve their sight. They can see and observe by themselves, especially in studying vocabulary. 
The Effectiveness of Flashcards on the Motivation to Increase English Vocabulary...

Wright (1976) states that flashcards are cards printed with words and/or pictures which can be handled easily by the teacher. The flashcards which is intended in the research is a square cardboard sheet seven by ten centimeters in size. Each cards contains a picture which the teacher himself can make or he can take from a magazine, newspaper, or book. At the bottom of each card, there is an English vocabulary item with its pronunciation and its translation into Indonesian. In the card, for example, there can be a picture of a table as well as the transcription of the pronunciation of the word"table" (teibl) and its translation "meja".

Stanford (in Effendi and Praja, 1985) states that motivation is an energizing condition of the organism toward the goal of certain class. Motivation derives from the latin word "movere". It means to move. A motive is what causes a person to act in a certain way (Yelon and Weinstein, 1977).

In teaching learning process, motivation gives a big influence on reaching the instructional objectives.cess, motivation gives a big influence on reaching the instructional objectives. There are some efforts to arouse motivation by giving a gift, praise, test, etc. Giving various motivations will give optimum results in the learning process. One of the alternatives to improve students' motivation to learn is by presenting media in the teaching learning process.

Hornby (1983) says that vocabulary is the total number of words which (with rules for combining them) make up a language. Vocabulary mastery is not a spontaneous process. It is a gradual process to aim the stable vocabulary mastery. According to Piagets' theory, a child at the age of 7-11 is always interested to recognize and know new words, he tends to repeat them again and again so that he will memorize them. The elementary school fourth-grade students are included in the pre-adolescent phase, during which he will be interested to know and to learn new words, like English vocabulary, for example.

The hypothesis of this study are proposed in the form of null and research hypothesis. The hypothesis are as follows:

$\mathrm{HO}=$ there is no significant difference between vocabulary mastery of the students thought through flashcards and that of the students thought without flashcards.

$\mathrm{Hi}=$ there is a significant difference between vocabulary mastery of the students taught through flashcards and that of the students thought without pictures.

The hypothesis were tested through the table of the critical values of $t$ (see Hatch nad Farhady, 1982). Since the number of the sample was 40 and the significance level was $5 \%$, the $t$ critical value was 2,021 . It means that if the $t$ obtained was less than 2,021 as its critical value, the null hypothesis 
would be accepted and the alternative hyothesis would be rejected. Conversely, if the obtained $t$ was the same as or higher than 2,021, the null hypothesis would be rejected consequentlythe alternative hypothesis would be accepted.

\section{METHODS}

The writer used an experimental method in this investigation. According to Richard, Platt, and Weber (1985:100), experimental method means an approach to an educational research in which an idea or a hypothesis is tested or verifiedby setting up situation in which the relatationship between subjects or variables can be determined. The term experimental method, according to Nazir (1985) is an observation under an artificial condition in which the condition is made and controlled by a researcher.

Experimental method was implemented in the form of the actual teaching to the sample. In applying the method, the writer devided test into two, pre-test and post-test.

\section{Population}

A population is a number of people with the same characteristics from which the data are collected. The population to which the results of this research is generalized consists of 30 fourth-grade students of SDN 71 Palembang of the 2001/2002 academic year. In this research, there is no sample, all students became the esearch subjects. Thus the research is called population research. Arikunto (1986) states that if the researcher intends to see all the elements in the research area, this kind of research is called population research.

\section{Instruments}

As mentioned in the previous paragraph, there are two techniques used in this study, namely, the test and observation. The vocabulary mastery test is developed based on the Local Content Curriculum for Basic Education for the English subject in the form of multiple choice. There are 40 items to be tried out in SDN 71 Palembang. The observation sheet, in the form of a questionnaire, shows the aspects that indicate motivation among the students. The aspects used are the interests, attention, diligence, activities, enthusiast, and material mastery. The quetionnaire used to collect the data on the students' English learning motivation consists of questions and statements based on the indicators on the orientations or goals of learning English, the factors in learning English, the efforts made by the students in learning English, and the result to be attained by the students in learning English. Each item consists of 4 alternatives for each questions or statements. 
The Effectiveness of Flashcards on the Motivation to Increase English Vocabulary...

On the other hand, the scale used in this instrument is likerts' scale. The scale value of $a=4, b=3, c=2, d=1$. The questions or statemnts in the instruments are answered by giving a check mark (V) on the chosen alternative. Before it was tried out, 34 questions or statements were developed. These consisted of three questions or statements of the orientation or goals in learning English, ten questions or statements of students' efforts in learning English and seven questions or statements of the results to be achieved by the students in learning English.

\section{Data Analysis Procedures}

\section{The techniques for Analyzing Data}

The data obtained were analyzed through three steps, they are:

1) Percentage anaysis was applied to know the individual score of the students both in the pre-test.

2) The conversion was used to interpret the students' score obtained both in the post test

3) Matched t-test

\section{Validity}

The validity that is used in this instrument is the content validity. Suharto (1988) defines content validity as how far an instrument represents or grasps the area that will be measured.

\section{Reliability}

Reliability is a measure of degree o which a test gives consistent result. A test is said to be reliable if it gives the same result when it is given on different occasions or when it is used by different people (Richards, et al 1985). The reliability of the test materials was evaluated through internal consistency reliability.

\section{FINDINGS}

There are four findings inthis investigation, (1) the students' scores obtained through the pre-test, (2) the students' scores obtained through the post-test, (3) the result of matched t-test, (4) the result of quetionnaire.

The average score that the students obtained in the pre-test was 67. The highest score was 90 that could be obtained by 2 students. And the lowest score was 50 that was 50 that was obtained by 2 students.

In the post-test the average score that the students got 78. This average score was much higher than that they obtained in the pre-test (67). Meanwhile, the highest score in the post-test was 10 that was obtained by 5 students. While the lowest scoe was 55 that was obtained only by 1 student. Again, the number of students who got the highest score exceeded those 
who obtained the highest score they got in the pre-test. Based on the data analysis, it was found that the $t$ obtained was 7,74 . This $t$ obtained was higher than 2,021 as its critical value.

For the motivation test, the score of item $\mathrm{A}($ selalu $)=1078$, item $\mathrm{B}$ (sering $)=384$, item $\mathrm{C}($ kadang-kadang $)=412$, and item $\mathrm{D}($ tidak pernah $)=134$. So the total score of the four items was 2008 , and the percentage was $7,69 \%$.

Table 1. The students' scores in the pre-test

\begin{tabular}{|c|c|c|c|}
\hline Number & $\begin{array}{l}\text { Correct } \\
\text { Answer }\end{array}$ & $\begin{array}{c}\text { Percentage } \\
(\%)\end{array}$ & Predicate \\
\hline 1 & 16 & 80 & Good \\
\hline 2 & 12 & 60 & Fair \\
\hline 3 & 10 & 50 & Fair \\
\hline 4 & 10 & 50 & Fair \\
\hline 5 & 16 & 80 & Good \\
\hline 6 & 12 & 60 & Fair \\
\hline 7 & 13 & 65 & Good \\
\hline 8 & 11 & 55 & Fair \\
\hline 9 & 12 & 60 & Fair \\
\hline 10 & 18 & 90 & Very good \\
\hline 11 & 12 & 60 & Fair \\
\hline 12 & 15 & 75 & Good \\
\hline 13 & 13 & 65 & Fair \\
\hline 14 & 13 & 65 & Fair \\
\hline 15 & 11 & 55 & Fair \\
\hline 16 & 16 & 80 & Good \\
\hline 17 & 15 & 75 & Good \\
\hline 18 & 16 & 80 & Good \\
\hline 19 & 11 & 55 & Fair \\
\hline 20 & 13 & 65 & Fair \\
\hline 21 & 12 & 60 & Fair \\
\hline 22 & 18 & 90 & Very good \\
\hline 23 & 13 & 65 & Fair \\
\hline 24 & 15 & 75 & Good \\
\hline 25 & 13 & 65 & Fair \\
\hline 26 & 14 & 70 & Good \\
\hline 27 & 13 & 65 & Fair \\
\hline 28 & 13 & 65 & Fair \\
\hline 29 & 14 & 70 & Good \\
\hline \multirow[t]{3}{*}{30} & 12 & 60 & Fair \\
\hline & Total & : 2010 & \\
\hline & Average & $\begin{array}{c}: 2010 / 30= \\
67\end{array}$ & Fair \\
\hline
\end{tabular}


The Effectiveness of Flashcards on the Motivation to Increase English Vocabulary...

Table 2. The students' scores obtained in the post-test

\begin{tabular}{cccc}
\hline Number & $\begin{array}{c}\text { Correct } \\
\text { Answer }\end{array}$ & $\begin{array}{c}\text { Percentage } \\
(\mathbf{\%})\end{array}$ & Predicate \\
\hline 1 & 16 & 80 & Good \\
2 & 15 & 75 & Good \\
3 & 15 & 75 & Good \\
4 & 13 & 65 & Good \\
5 & 20 & 100 & Very good \\
6 & 14 & 70 & Good \\
7 & 16 & 80 & Good \\
8 & 13 & 65 & Good \\
9 & 15 & 75 & Good \\
10 & 20 & 100 & Very good \\
11 & 14 & 70 & Good \\
12 & 15 & 75 & Good \\
13 & 14 & 70 & Good \\
14 & 20 & 100 & Very good \\
15 & 11 & 55 & Fair \\
16 & 15 & 75 & Good \\
17 & 16 & 80 & Good \\
18 & 20 & 100 & Very good \\
19 & 12 & 60 & Fair \\
20 & 15 & 75 & Good \\
21 & 15 & 75 & Good \\
22 & 20 & 100 & Very good \\
23 & 16 & 80 & Good \\
24 & 15 & 75 & Good \\
25 & 13 & 65 & Good \\
26 & 16 & 80 & Good \\
27 & 16 & 80 & Good \\
28 & 16 & 80 & Good \\
29 & 16 & 80 & Good \\
30 & 16 & 80 & Good \\
& Total & $: 2340$ & Good \\
\hline & Average & $: 2340 / 30$ & \\
\hline
\end{tabular}

Table 3. The Result of the Matched T-Test

\begin{tabular}{ccccc}
\hline Number & Pre-test & Post-test & D & D2 \\
\hline 1 & 80 & 80 & 0 & 0 \\
2 & 60 & 75 & 15 & 225 \\
3 & 50 & 75 & 25 & 625 \\
4 & 50 & 65 & 15 & 225 \\
5 & 80 & 100 & 20 & 400 \\
6 & 60 & 70 & 10 & 100 \\
7 & 65 & 80 & 15 & 225 \\
8 & 55 & 65 & 20 & 400 \\
\hline
\end{tabular}




\begin{tabular}{ccccc}
\hline Number & Pre-test & Post-test & D & D2 \\
\hline 9 & 60 & 75 & 75 & 225 \\
10 & 90 & 100 & 10 & 100 \\
11 & 60 & 70 & 10 & 100 \\
12 & 75 & 75 & 0 & 0 \\
13 & 65 & 70 & 5 & 25 \\
14 & 65 & 100 & 35 & 225 \\
15 & 55 & 55 & 0 & 0 \\
16 & 80 & 75 & 5 & 25 \\
17 & 75 & 80 & 5 & 25 \\
18 & 80 & 100 & 20 & 400 \\
19 & 55 & 60 & 5 & 25 \\
20 & 65 & 75 & 10 & 100 \\
21 & 60 & 75 & 15 & 225 \\
22 & 90 & 100 & 10 & 100 \\
23 & 65 & 80 & 15 & 225 \\
24 & 75 & 75 & 0 & 0 \\
25 & 65 & 65 & 0 & 0 \\
26 & 70 & 80 & 10 & 100 \\
27 & 65 & 80 & 15 & 225 \\
28 & 65 & 80 & 15 & 225 \\
29 & 70 & 80 & 10 & 100 \\
30 & 60 & 80 & 20 & 400 \\
& D $=350$ & D2=3717 & & \\
\hline
\end{tabular}

$S D=\frac{S D}{\sqrt{n-1}},=\frac{D-(1 / n)(D)}{\sqrt{n-1}}$

$S D=\frac{3717-(1 / 30)(350)}{\sqrt{30-1}},=S D=\frac{3717-(1 / 30)(350)}{\sqrt{30-1}},=$

$S D=\frac{3717-(0.03)(122500)}{\sqrt{29}},=S D=\frac{3717-3675}{5,39},=S D=\frac{42}{5,39}, \mathrm{SD}=7,79$

$S D=\frac{S D}{\sqrt{n}},=S D=\frac{7,79}{\sqrt{30}},=S D=\frac{7,79}{5,48}, \mathrm{SD}=1,42$

$\mathrm{t}=\frac{X 1-X 2}{S D}=\frac{78-67}{1,42}=7,74$

Based on the two results of the pre-test and the post-test in this study, the value of $\mathrm{t}$-calculation with the percentage score in the pre-test 67 and in the post-test 78. It means that $\mathrm{Hi}$ was excepted or there is a significant difference between the students score in the pre-test and those in the posttest of English vocabulary mastery. 
Table 4. The Result of Questionnaire

\begin{tabular}{|c|c|c|c|c|c|}
\hline $\begin{array}{c}\begin{array}{c}\text { Number } \\
\text { of } \\
\text { Students }\end{array} \\
\text { Studen }\end{array}$ & $\begin{array}{c}\text { Selalu } \\
\text { (A) } \\
4\end{array}$ & $\begin{array}{c}\text { Sering } \\
\text { (B) } \\
3\end{array}$ & $\begin{array}{c}\text { Kadang } \\
\text { (C) } \\
2\end{array}$ & $\begin{array}{c}\text { Tidak Pernah } \\
\text { (D) } \\
1\end{array}$ & $\begin{array}{c}\text { SCORE } \\
A+B+C+D\end{array}$ \\
\hline 1 & 32 & 24 & 8 & 10 & 74 \\
\hline 2 & 32 & 27 & 6 & 10 & 75 \\
\hline 3 & 40 & 30 & 4 & 8 & 82 \\
\hline 4 & 36 & 21 & 14 & 8 & 79 \\
\hline 5 & 32 & 15 & 20 & 7 & 74 \\
\hline 6 & 36 & 18 & 10 & 10 & 74 \\
\hline 7 & 36 & 30 & 16 & 3 & 8581 \\
\hline 8 & 28 & 30 & 20 & 3 & 58 \\
\hline 9 & 8 & 21 & 16 & 13 & 78 \\
\hline 10 & 36 & 24 & 10 & 8 & 78 \\
\hline 11 & 32 & 24 & 16 & 6 & 94 \\
\hline 12 & 36 & 24 & 16 & 18 & 60 \\
\hline 13 & 20 & 15 & 10 & 15 & 70 \\
\hline 14 & 20 & 21 & 14 & 11 & 56 \\
\hline 15 & 16 & 6 & 20 & 14 & 77 \\
\hline 16 & 32 & 27 & 10 & 8 & 57 \\
\hline 17 & 28 & 9 & 9 & 11 & 79 \\
\hline 18 & 32 & 22 & 2 & 4 & 57 \\
\hline 19 & 28 & 36 & 6 & 7 & 36 \\
\hline 20 & 6 & 6 & 8 & 18 & 72 \\
\hline 21 & 32 & 12 & 20 & 8 & 63 \\
\hline 22 & 20 & 15 & 16 & 12 & 89 \\
\hline 23 & 32 & 45 & 10 & 2 & 65 \\
\hline 24 & 36 & 9 & 4 & 16 & 51 \\
\hline 25 & 20 & 3 & 8 & 20 & 88 \\
\hline 26 & 40 & 24 & 4 & 10 & 91 \\
\hline 27 & 40 & 42 & 6 & 3 & 77 \\
\hline 28 & 40 & 21 & 6 & 10 & 77 \\
\hline 29 & 24 & 33 & 14 & 6 & 69 \\
\hline 30 & 28 & 21 & 10 & 10 & 72 \\
\hline 31 & 36 & 18 & 6 & 2 & 62 \\
\hline 32 & 20 & 12 & 18 & 12 & 66 \\
\hline 33 & 28 & 12 & 4 & 12 & 66 \\
\hline 34 & 32 & 3 & 6 & 15 & 56 \\
\hline Total & 1078 & 384 & 412 & 134 & $2008=76,6 \%$ \\
\hline
\end{tabular}

Based on the criteria of testing the hypothesis, alternative hypothesis (Hi) was tasted through the t- table (see Hatch and Farhady, 1982). Since the number of samples of this research was 30 students, so to accept the alternative hypothesis with $5 \%$ significant, the $t$ - value of the matched $t$-test calculation should exceed 2,021. Based on the result of the data analysis the 
value of $t$-calculation was 7,74, it was higher than 2,021 as its critical value. It means that the use of teaching English vocabulary by using flashcard enable the students to get better scores.

While the result of questionnaire scores above showed that students have high motivation in studying English $(76,6 \%)$ give positive responses and the factors that can influence the students motivation were intrinsic and extrinsic motivation.

\section{DISCUSSION}

Based on the criteria of testing the hypothesis, alternative hypothesis (Hi) was tasted through the $\mathrm{t}$ - table (see Hatch and Farhady, 1982). Since the number of samples of this research was 30 students, so to accept the alternative hypothesis with 5\% significant, the $t$ - value of the matched t-test calculation should exceed 2,021. Based on the result of the data analysis the value of $t$-calculation was 7,74 , it was higher than 2,021 as its critical value. It means that the use of teaching English vocabulary by using flashcard enable the students to get better scores.

While the result of questionnaire scores above showed that students have high motivation in studying English $(76,6 \%)$ give positive responses and the factors that can influence the students motivation were intrinsic and extrinsic motivation.

\section{CONCLUSION AND SUGGESTION}

Based on the previous discussion, general conclusions were drawn. First, there is a significant difference between the motivation to learn English vocabulary among the elementary school fourth-grade students before the implementation of flashcards and that after the implementation of flashcards. Therefore, the flashcards can be given to the students following the presentation of the words taught.

Second, there is a significant difference between the English vocabulary mastery of elementary school fourth-grade students before and after being taught by using flashcards. The flashcards were proved to gain a better result when they were used as follow-up exercises in teaching vocabulary to elementary school fourth grade students. The students given flashcards were able to master a greater number of words than the students that not given.

Using illustrated media (flashcards), it is not only improving students' motivation in learning English but also make the students active in learning. By using this technique, there will be many adventages that will be got by the students in developing their English. And also for the English teacher, in applying flashcards as an illustrated media, he can create the 
The Effectiveness of Flashcards on the Motivation to Increase English Vocabulary...

situation and give the students opportunities to get involved in the classroom activities.

\section{REFERENCES}

Arikunto, S. 1987. Prosedur Penelitian Suatu Pendekatan Praktek. Jakarta : Bina Aksara.

Brown, J.W., Lewis, R.B., and Harcleroad, F. 1977. AV Instruction, Technology, Media and Methods (5Th edition). USA : Mc. Graw-Hill, Inc.

Effendi, U. And Praja, J.S. 1985. Pengantar Psikologi. Bandung : Aksara

French, F.G. 1950. The teaching of English Aboard (3rd edition). London : oxford University Press.

Hamalik, O. 1985. Media Pendidikan. Bandung : Alumni.

Hornby, A.S. 1983. Guide to Patterns and Usage in English. New York : Oxford University Press.

Rinanto, A. 1982. Peranan Media Audiovisual dalam Pendidikan. Yogyakarta : Yayasan Kanius.

Wright, A. 1976. Klasifikasi Media Pendidikan. Bandung : Alumni.

Yelon, S.L. and Weinstein, G.W. 1977. A Teacher's World, Psychology in the Classroom. USA : Mc. Graw-Hill. Inc. 